\title{
MENERAPKAN KEGIATAN MEWARNAI DENGAN ANEKA MEDIA UNTUK MENINGKATKAN KEMAMPUAN VISUAL-SPASIAL PADA ANAK USIA DINI
}

\author{
Aisyah $^{1)}$, Ismawati ${ }^{1)}$ * \\ ${ }^{1}$ Jurusan PG-PAUD, Universitas Halu Oleo.Jln. H.E.A Mokodompit, Kendari 93232, Indonesia
}

Korespondensi Penulis. E-mail: ismawati070995@gmail.com, Telp: 082292398885

\begin{abstract}
Abstrak
Anak usia dini adalah individu yang sedang mengalami pertumbuhan dan perkembangan yang sangat pesat, dan menempati kedudukan sebagai masa golden age. Dunia anak adalah dunia bermain. Bermain merupakan aktivitas yang sangat penting dan menyenangkan dalam kehidupan anak. Ketika anak bermain ia bebas untuk berbuat apa saja. Dalam kegiatan bermain, khususnya kegiatan mewarnai pada aneka media dapat mengembangkan berbagai kemampuan anak salah satunya adalah kemampuan visual-spasialnya. Dalam kegiatan mewarnai anak dapat mencurahkan serta menuangkan semua ide yang ada dalam pikirannya lewat warna dan tulisan dari alat warna dan akan memberi stimulus bagi otak kanan dan otak kiri anak. Kegiatan mewarnai juga digunakan sebagai media berekspresi, dapat mengenal perbedaan warna, dapat meningkatkan konsentrasi, melatih mengenai objek sehingga anak memahami detail objek yang akan diwarnai, melatih anak mengenal aneka warna dan nama-nama warna, membantu anak untuk belajar keserasian dan keseimbangan warna, dan dapat merangsang kepakaan anak terhadap warna.
\end{abstract}

Kata kunci: Kegiatan Mewarnai, Aneka Media Mewarnai, Visual-spasial

\section{THE IMPLEMENTATION OF COLORINGACTIVITIES WITH A VARIETY OF MEDIA TO IMPROVE THE ABILITY OF VISUAL-SPATIAL ON EARLY CHILDHOOD}

\begin{abstract}
Early childhood is an individual who is experiencing growth and development which are very rapidly, and occupies the position as the golden age. The child's world is the world of the play. Play is a very important activity and fun in the lives of children. When children play he is free to do just about anything. In play activities, particularly activities of coloring on a variety of media can develop various capabilities of the children one of which is the ability of the visual-spasialnya. In the activities of coloring can pour out and poured all the ideas that were in his mind through the color and the color of the tool and will provide a stimulus for the right brain and left brain. Activities coloring is also used as a medium of expression, can know the difference of color, can increase concentration, trained on the object so that the child understand the detail object that will be colored, train the child to know a variety of colors and color names, help children to learn harmony and color balance, and can stimulate the child's kepakaan against the color.
\end{abstract}

Keywords: Coloringactivity, Coloring Media, Visual-spatial

\section{PENDAHULUAN}

Anak adalah titipan Tuhan yang harus di jaga dan dididik agar menjadi manusia yang berguna dan tidak menyusahkan siapa saja. Secara umum anak mempunyai hak dan kesempatan untuk berkembang sesuai potensinya terutama dalam bidang pendidikan.
Fadillah (2012: 53) pendidikan memiliki peranan yang sangat menentukan bagi perkembangan dan perwujudan diri individu anak, terutama bagi pembangunan bangsa dan negara. Pendidikan tidak hanya dimaknai sebagai transfer pengetahuan. Pendidikan berarti proses pengembangan berbagai 
macam potensi yang ada di dalam diri anak, seperti kemampuan akademis, relasional, bakat-bakat, talenta, kemampuan fisik dan dayadaya seni. Dalam bidang pendidikan seorang anak dari lahir memerlukan pelayanan yang tepat dalam pemenuhan kebutuhan pendidikan disertai dengan pemahaman mengenai karakteristik sesuai dengan pertumbuhan dan perkembangan anak. Dengan pelayanan yang tepat, akan membantu anak dalam menyesuaikan proses belajar, kebutuhan, dan kondisi masing-masing, baik secara intelektual, emosional dan sosial.

Association for the Education Young Chilldren (NAEYC) atau "early childhood" menyatakan bahwa anak usai dini merupakan anak yang berada pada usia nol sampai dengan usia delapan tahun. Pada masa tersebut merupakan proses pertumbuhan dan perkembangan dalam berbagai aspek dalam rentang kehidupan manusia misalnya perkembangan fisik motorik, kognitif, bahasa, seni, sosial emosional dan agama. Proses pembelajaran terhadap anak harus memerhatikan karakteristik yang dimiliki dalam tahap perkembangan anak.

Anak usia dini adalah individu yang sedang mengalami pertumbuhan dan perkembangan yang sangat pesat, dan menempati kedudukan sebagai masa golden age. Anak usia dini memiliki rentang usia yang sangat berharga dibanding usia-usia selanjutnya karena perkembangan kecerdasannya sangat luar biasa. Usia tersebut merupakan fase kehidupan yang unik, dan berada pada masa proses perubahan berupa pertumbuhan, perkembangan, pematangan, dan penyempurnaan, baik pada aspek jasmani maupun rohaninya yang berlangsung seumur hidup bertahap dan berkesinambungan.

Gardner dalam Armstrong (2013: 6) menyatakan bahwa kecerdasan lebih berkaitan dengan kapasitas/kemampuan untuk: (1) memecahkan masalah-masalah, (2) menciptakan produk-produk dan karyakarya dalam sebuah konteks yang kaya serta keadaan yang naturalistik. Gardner menyediakan sarana untuk memetakan berbagai kemampuan yang harus dimiliki oleh anak, dengan mengelompokkan kemampuan-kemampuan tersebut kedalam delapan kategori yang komperhensif atau "kecerdasan" berikut ini: kecerdasan linguistik, kecerdasan logis matematis, kecerdasan spasial, kecerdasan kinestetik- tubuh, kecerdasan musikal, kecerdasan interpersonal, kecerdasan intrapersonal dan kecerdasan naturalis. Kedelapan kecerdasan tersebut perlu dikembangkan secara maksimal sesuai dengan potensi dan bakat yang ada pada anak, termasuk didalamnya kecerdasan visual spasial.

Suyadi (2009: 175) mengatakan bahwa kecerdasan visual spasial adalah kemampuan untuk melihat suatu objek dengan sangat detail. Kemudian, ia mampu merekam apa yang ia lihat tersebut dalam memori otaknya dalam jangka waktu yang sangat lama. Selain itu, jika suatu saat ia ingin menjelaskan apa yang dilihatnya tersebut kepada orang lain, ia mampu melukiskannya dalam selembar kertas dengan sangat sempurna. Diperjelas oleh Olivia (2009:82) kecerdasan visual spasial adalah kemampuan berpikir menggunakan visual atau gambar dan membayangkan dalam pikiran dalam bentuk dua tiga dimensi.

Gardner dalam Musfiroh (2008: 14) mengungkapkan kecerdasan visual spasial anak usia dini dapat dikembangkan dengan berbagai cara, meliputi kegiatan bermain, menggambar atau melukis, mewarnai, karyawisata, imajinasi, bercerita, proyek, dan dekorasi permainan. Berbagai aneka media yang dapat digunakan untuk kegiatan mewarnai guna meningkatkan kemampuan visual spasial anak usia dini diantaranya pensil warna, pelepah pisang, kunyit, krayon

\section{KEMAMPUAN VISUAL-SPASIAL PADA ANAK USIA DINI}

Armstrong dalam Musfiroh (2008: 34) kemampuan visual-spasial adalah kemampuan mempersepsi dunia visual-spasial secara akurat serta mentrasnformasikan persepsi visualspasial tersebut dalam berbagai bentuk. Mempersepsi yakni menangkap dan memahami sesuatu melalui panca indra atau sesuatu yang terkait dengan kemampuan mata khususnya mata dan ruang. Mentransformasikan yaitu mengalihbentukkan hal yang ditangkap oleh mata kedalam wujud lain misalnya melihat dan mengamati bunga matahari lalu direkam dan menginterpretasikan dalam pikiran lalu menuangkan pikiran interpretasi tersebut ke dalam bentuk lukisan, sket atau lukisan kain perca. Kemampuan berfikir visual-spasial merupakan kemampuan berfikir dalam bentuk visualisasi, gambar dan bentuk tiga dimensi. Anak dengan kemampuan visual-spasial 
mempunyai kepekaan terhadap warna, bentuk, ruang, keseimbangan, bayangan, pola dan hubungan antar unsur.

$$
\text { Lebih lanjut Ali (2003: 123) }
$$
mengemukakan bahwa kecerdasan visualspasial adalah kumpulan dari berbagai keahlian yang saling berkaitan, yang meliputi kemampuan untuk mengenali identitas sebuah objek yang ada didepannya dari sudut pandang yang berbeda, kemampuan untuk membayangkan perubahan sebuah konfigurasi ketika komponen konfigurasi itu dirubah atau dipindah, misalnya pada saat bermain balok, anak dapat membayangkan apabila sebuah balok dipindahkan nanti akan membentuk sebuah bangunan seperti yang ia inginkan dan kemampuan untuk memahami hubungan spasial antara dirinya dengan benda lain misalnya pada saat anak naik sepeda ia dapat memperkirakan jarak dirinya dengan sebuah pohon.

Anak-anak dengan kecerdasan visualspasial yang tinggi cenderung berpikir dengan berimajinasi. Kecerdasan visual-spasial adalah kemampuan untuk membentuk suatu gambaran tentang tata ruang didalam pikiran, anak kaya khayalan internal (internal imagery) sehingga cenderung imajinatif dan kreatif. Mereka mampu memanipulasi dan menciptakan gambar di dalam pikiran mereka. Selain itu juga, anakanak dengan kemampuan visual-spasial menyukai kegiatan bermain puzzle, menggambar, bermain balok, bermain maze, membangun bentuk, serta berimajinasi membentuk bangunan-bangunan lewat permainan. Cara belajar terbaik untuk anak yang cerdas visual-spasial adalah melalui warna, coretan, arah, bentuk dan ruang.

Berdasarkan pendapat di atas, dapat disimpulkan bahwa kemampuan visual-spasial merupakan kemampuan untuk mempersepsi dunia visual spasial secara akurat serta mentransformasikan visual spasial tersebut ke dalam berbagai bentuk, kemampuan untuk membentuk suatu gambaran tentang tata ruang didalam pikiran, sehingga anak kaya khayalan imajinatif dan kreatif serta kemampuan untuk mengenali identitas sebuah objek yang ada di depannya dari sudut pandang yang berbeda.

Armstrong dalam Musfiroh (2002: 4.7) juga mengungkapkan ciri-ciri anak dengan kecerdasan visual-spasial yaitu anak senang membuat dan mempelajari peta, tabel, diagram dan skema, anak senang membuat coretancoretan atau sketsa, mudah menghafal jalan yang pernah dilewati, dan anak senang menjelaskan sesuatu menggunakan gambar, denah atau gambar lainnya. Anak-anak yang kemampuan visual-spasialnya tinggi, ia berfikir dengan gambar, biasanya mereka menyukai kegiatan bermain puzzle, menggambar, bermain balok, bermain maze, membangun bentuk, serta berimajinasi membentuk bangunan-bangunan lewat permainan. Aktivitas yang dapat dilakukan untuk mengembangkan kemampuan visual-spasial adalah menggambar, mewarnai, melengkapi gambar, finger painting, bermain plastisin, dan bermain geometri. Hal ini di perjelas oleh pendapat (Sujiono, 2005) bahwa anak yang memiliki kecerdasan visual spasial tinggi memiliki ciri-ciri, antara lain: (1) senang bermain dengan bentuk dan ruang (rancang bangun); (2) hafal jalan yang pernah dilewati; (3) aktif mengerjakan hal-hal yang berkaitan dengan abstraksi ruang; (4) memiliki daya problem solving atau pemecah-an masalah yang baik; (5) senang mengukur mana yang lebih panjang dan pendek, besar kecil, jauh dan dekat; (6) dapat menangkap perkira-an atau jarak; dan (7) memiliki perhatian tinggi terhadap detail. Kecerdasan visual anak dapat dikem-bangkan melalui beberapa cara, yaitu: (1) mencoret-coret; (2) menggambar dan melukis; (3) membuat prakarya atau kerajinan tangan yang menuntut anak untuk memanipulasi bahan; (4) mengunjungi berbagai tempat agar dapat memperkaya pengalaman visual anak; (5) melakukan permainan konstruktif dan kreatif; dan (6) mengatur dan merancang dengan mengajaknya dalam kegiatan mengatur ruang di rumah.

Penajaman kemampuan visual-spasial mengacu pada kegiatan yang mengutamakan kemampuan mengidentifikasi, membandingkan dan menganalisis ciri dan karakteristik benda. Penajaman kemampuan visual-spasial dapat dilakukan dengan berbagai cara antara lain:

1. Latihan observasi

Latihan observasi adalah kegiatan bermain dengan mengamati alat-alat permainan yang akan digunakan. Kegiatan ini bertujuan untuk merangsang persepsi visual anak melalui objek langsung.

2. Bermain teropong kertas

Bermain teropong kertas adalah kegiatan bermain yang dilakukan untuk menfokuskan pandangan anak pada suatu benda. Kegiatan ini bertujuan untuk merangsang kemampuan mengamati fitur-fitur dari suatu objek tertentu.

3. Bermain kaca pembesar. 
Kaca pembesar merupakan kegiatan bermain untuk melihat objek kecil-kecil. Kegiatan ini bertujuan merangsang kemampuan anak mengamati objek kecil yang sulit dilihat oleh mata.

Selain ciri-ciri yang telah disebutkan tersebut, kemampuan visual-spasial juga mempunyai beberapa indikator yaitu :

1. Individu yang cerdas secara visual-spasial lebih mudah membaca peta, gambar, grafik dan diagram

2. Individu yang cerdas secara visual-spasial menonjol dalam seni lukis dan seni kriya

3. Individu yang cerdas secara visual-spasial mampu memberikan gambar visual yang jelas ketika sedang memikirkan sesuatu

4. Individu yang cerdas secara visual-spasial mampu menggambar sosok orang atau benda menyerupai bentuk aslinya

5. Individu yang cerdas secara visual-spasial senang menikmati permainan yang membutuhkan ketajaman visual-spasial seperti jigsaw dan maze.

6. Individu yang cerdas secara visual-spasial sering melamun, membayangkan sesuatu, dan mengembangkan imajinasi mereka.

\section{KEGIATAN MEWARNAI PADA ANAK USIA DINI}

Kegiatan mewarnai adalah kegiatan membubuhkan warna atau cat pada suatu gambar. Mewarnai sudah menjadi media untuk anak-anak berimajinasi, bereksplorasi dan berinspirasi melalui pengalaman yang telah mereka alami sebelumnya (Muhammad, 2009: 11-12). Selain itu, kegiatan bermain mewarnai juga merupakan aktivitas yang menyenangkan bagi anak-anak dimana anak diajak untuk memberi warna melalui berbagai media baik saat menggambar atau meletakkan warna saat mengisi bidang-bidang gambar yang harus diberi warna pada suatu bentuk atau pola gambar, sehinga terciptalah sebuah kreasi seni.

Kegiatan mewarnai juga merupakan kegiatan yang sering diberikan di KB dan TK. Dengan demikian, anak usia 3 tahun dapat diberi kesempatan mewarnai dengan krayon, pensil warna atau spidol asalkan pada saat anak mewarnai tidak lepas dari pengawasan guru atau orang tua. Kegiatan mewarnai dapat dilakukan dengan dua cara yaitu mewarnai bebas dan mewarnai sesuai petunjuk. Mewarnai bebas dilakukan untuk mengasah kepekaan aristik, dan mewarnai sesuai petunjuk dimaksudkan sebagai stimulasi kepekaan warna.
Adanya kegiatan mewarnai anak dapat mencurahkan serta menuangkan semua ide yang ada dalam pikirannya lewat warna dan tulisan dari alat warna dan akan memberi stimulus bagi otak kanan dan otak kiri anak. Kegiatan mewarnai sudah menjadi ajang untuk anak terus melatih kreativitas dan kemampuannya karena dengan mewarnai anak bisa menjadi lebih fokus untuk menyelesaikan pekerjaan yang sedang ia lakukan meskipun banyak hal yang terjadi disekitarnya. Selain untuk melatih kreatvitas, mewarnai juga menambah imajinasi anak. Mereka bisa mengimajinasikan pikiran mereka.

Pada kegiatan mewarnai pemilihan warna sangat penting untuk anak karena dapat melatih menanamkan sikap anak untuk memilih warna yang mereka anggap bagus dan ia sukai sebagai awal penanaman sikap anak terhadap apa yang ia hadapi, sedangkan menyusun warna dapat melatih nilai-nilai perbandingan yang bersifat rasa antara satu dengan lainnya, melatih bagaimana memilih dan menempatkan bagian satu dengan yang lainnya dan menuangkan warna adalah tindakan fisik dimana anak melakukan gerakan mengoles dan mengendalikan gerak tangan.

Musfiroh (2008) berpendapat mewarnai pada anak usia dini bertujuan untuk merangsang kepekaan anak terhadap warna dan merangsang kemampuan anak untuk memadukan warna. Selain itu juga dapat melatih kosentrasi, keterampilan, kerapian dan kesabaran. Dalam kegiatan mewarnai dibutuhkan kesabaran agar anak berkosentrasi untuk memilih dan menentukan warna-warna yang akan dia gunakan dengan memperhatikan keterampilan tangan dan kerapian warna pada saat mewarnai gambar. Mewarnai juga mempunyai manfaat untuk mengembangkan kemampuan motorik, sebagai media berekspresi, mengenal perbedaan warna, melatih anak memegang pensil, meningkatkan kosentrasi, melatih kemampuan bekerjasama, mengenal garis batas bidang, melatih anak membuat target, melatih mengenai objek sehingga anak memahami detail objek yang akan diwarnai terlebih dahulu sebelum mereka mewarnai, Melatih anak mengenal aneka warna dan nama-nama warna, melatih anak untuk memilih kombinasi warna dan membantu anak untuk belajar keserasian dan keseimbangan warna, dan Stimulasi daya imajinasi dan kreativitas 


\section{ANEKA MEDIA YANG DIGUNAKAN UNTUK KEGIATAN MEWARNAI PADA ANAK USIA DINI}

Beberapa aneka media yang dapat digunakan anak untuk mewarnai yaitu kertas, kain, tembok, papan, dupleks, dan lain-lain. Mewarnai dengan menggunakan berbagai aneka media ini dapat mengembangkan kreativitas anak karena anak diberikan kebebasan untuk bereksplorasi. Selain iu, mewarnai dengan berbagai aneka media dapat mengembangkan aspek berbahasa anak, kognitif, sosial emosional, fisik motorik, dan seni. Pengembangan kreativitas anak dalam aspek kognitif yaitu anak dapat membedakan macammacam warna dan memilih warna, sedangkan pengembengan kreativitas anak dalam aspek bahasa yaitu anak dapat menyebutkan macammacam warna, kemudian pengembangan kreativitas anak dalam aspek sosial emosional yaitu anak dapat berinteraksi dengan temantemannya dalam kegiatan mewarnai, serta pengembangan kretivitas anak dalam aspek fisik motorik yaitu anak dapat memadukan berbagai macam-macam warna untuk digunakan dalam kegiatan mewarnai, dan pengembangan kreativitas anak dalam aspek seni yaitu anak dapat mewarnai gambar dengan tidak keluar garis.

Beberapa gambar kegiatan anak dalam mewarnai dengan berbagai media sebagai berikut:

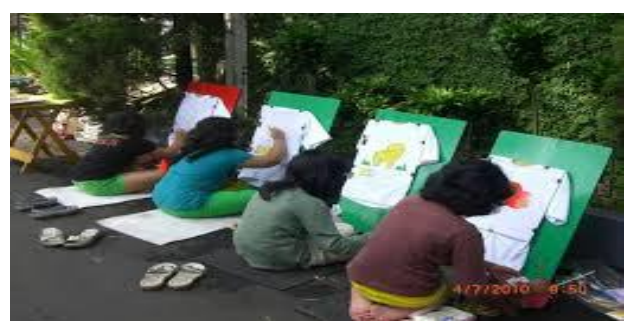

Gambar 1. Mewarnai Pada Media Kain

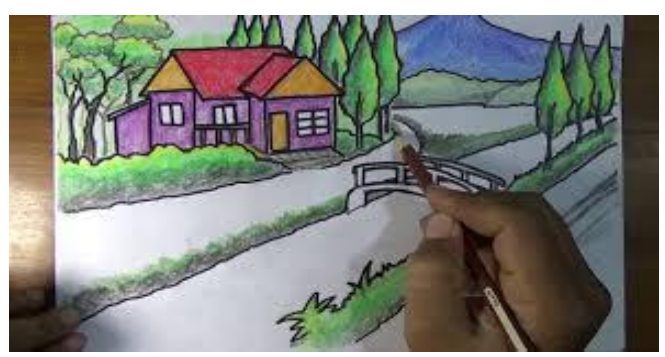

Gambar 2. Mewarnai Pada Media Kertas

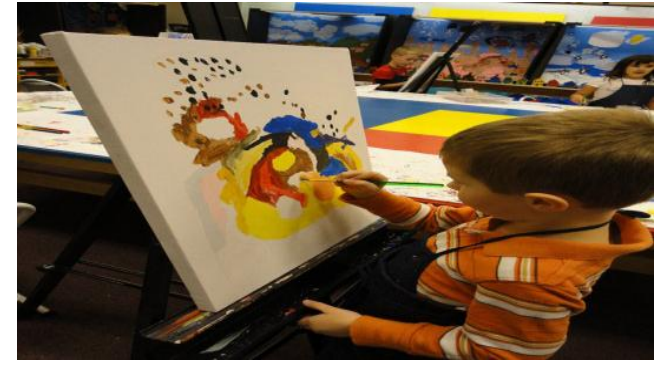

Gambar 3. Mewarnai Pada Media Kanvas

Adapun alat-alat yang digunakan untuk mewarnai yaitu pensil warna, krayon, cat air, pewarna makanan, kuas, dan pelepah pisang dan media bahan alam. Beberapa aneka media bahan alam yang digunakan untuk mewarnai yaitu kunyit, bunga rumput dan putren jagung. Media ini sangat aman untuk digunakan anak-anak karena tidak mengandung racun dan bau yang tajam. Jadi, anak-anak bebas untuk mewarnai dengan menggunakan media ini. Selain itu juga kreativitas anak dapat berkembang karena mereka menggunakan media yang berbeda-beda dalam mewarnai.

\section{MEWARNAI DENGAN PENSIL WARNA}

Dalam mewarnai dengan menggunakan pensil warna dapat dilakukan dengan beberapa teknik atau cara seperti cara memegang pensil warna. Cara memegang pensil warna ada tiga yaitu pensil warna dipegang seperti memegang pensil atau pena, pensil warna dipegang seperti memegang pisau, dan pensil warna warna dipegang seperti memegang sekop. Memegang pensil warna seperti memegang pensil atau pena akan menghasilkan gambar yang rapi, namun akan menyebabkan jari jemari cepat lelah bila digunakan mewarnai pada bidang gambar yang besar. Sedangkan memegang pensil seperti memegang pisau akan menghasilkan gambar yang lebih merata pada gambar bidang besar, namun tenanga yang digunakan lebih besar, dan memegang pensil seperti memegang sekop akan menghasilkan warna gambar yang tipis namun tetap merata.

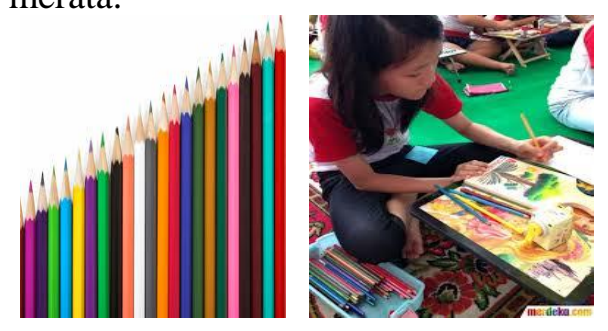

Gambar 4. Mewarnai Dengan Pensil Warna 


\section{MEWARNAI DENGAN CRAYON}

Mewarnai dengan crayon sangat baik untuk melatih perkembangan motorik anak. Namun untuk menghasilkan gambar dengan warna yang merata dapat digunakan beberapa cara yang tepat untuk mewarnai dengan crayon yaitu membuka label pada setiap batang crayon, mematahkan crayon sesuai yang diperlukan untuk mewarnai bidang gambar, dan torehkan crayon pada bidang gambar seperti menorehkan kapur tulis atau penghapus. Dengan membuka label pada setiap batang crayon dapat membuat anak lebih leluasa untuk mewarnai, sedangkan mematahkan crayon sesuai yang diperlukan agar bagian crayon yang lain bisa digunakan untuk mewarnai selanjutnya dan menorehkan crayon pada bidang gambar yaitu agar dapat mempercepat proses mewarnai dan menghasilkan efek yang bermotif.
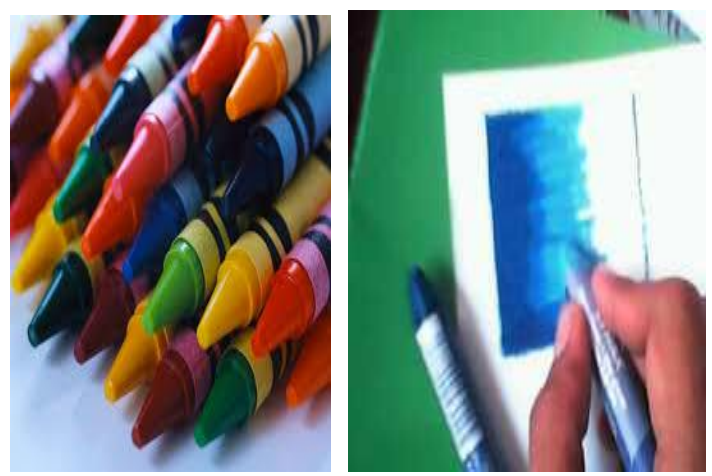

Gambar 5. Mewarnai Dengan Crayon

\section{MEWARNAI DENGAN CAT AIR}

Mewarnai dengan menggunakan cat air dapat dilakukan dengan menggunakan tangan. Anak-anak diberi kebebasan dalam berkreasi dengan menggunakan jari-jari tangan mereka. Selain menggunakan jari-jari tangan bisa juga dengan menggunakan kuas. Kegiatan ini sangat menyenangkan untuk anak-anak dan sangat di gemari anak.
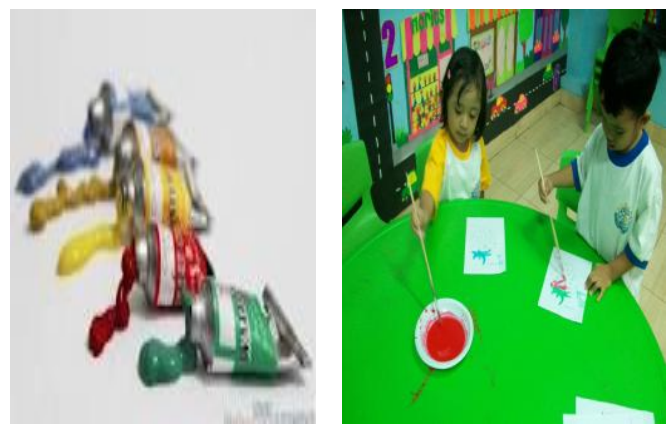

Gambar 6. Mewarnai Dengan Cat Air

\section{MEWARNAI DENGAN PELEPAH PISANG}

Pelepah pisang merupakan media yang aman untuk digunakan oleh anak-anak karena tidak mengandung racun dan dapat digunakan untuk anak belajar mewarnai. Mewarnai dengan menggunakan pelepah pisang dapat membuat lebih berfikir kreatif untuk bisa membuat motif yang sesuai dengan keinginannya misalnya anak membuat motif bunga, ia dapat menggambar dan mewarnai tangkainya, daunnya dan potnya.
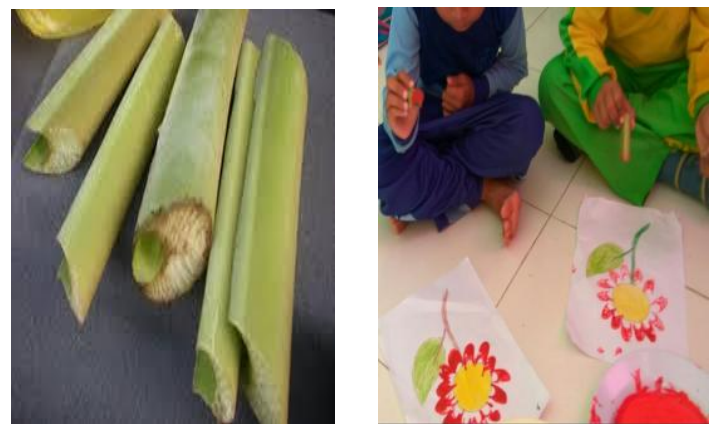

Gambar 7. Mewarnai Dengan Pelepah Pisang

\section{MEWARNAI DENGAN BAHAN MAKANAN (KUNYIT)}

Kunyit merupakan tanaman herbal. Batang kunyit semu, tegak, bulat, membentuk rimpang dan berwarna hijau kekuningan. Daunnya tunggal berbentuk lanset memanjang, ujung dan pangkal daun runcing tepi daun rata, pertulangan menyirip dan berwarna hijau. Tanaman ini sangat bermanfaat untuk kesehatan tubuh. Selain bermanfaat untuk kesehatan tubuh kunyit juga biasa digunakan sebagai media untuk pembelajaran di TK yaitu untuk mewarnai. Kunyit ini bisa digunakan untuk mewarnai setelah dikupas lalu digunakan dan bisa juga dikasih halus baru diaduk pake air. Selain itu juga batangnya bisa digunakan untuk membentuk pola bunga seperti pola bentuk bunga mawar.
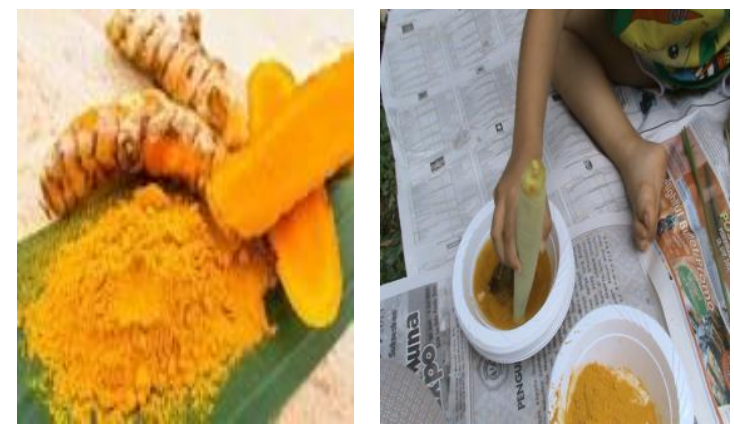

Gambar 8. Mewarnai Dengan Bahan Makanan 


\section{MEWARNAI DENGAN BUNGA RUMPUT}

Sebagian banyak orang menganggap bahwa rumput itu tidak penting, hanya dianggap jadi pengganggu saja untuk lingkungan utamanya lingkungan disekitar halaman rumah. Perlu diketahui bahwa banyak macam-macam rumput, ada rumput yang berbunga dan ada rumput yang tidak berbunga. Rumput berbunga ini bisa digunakan untuk media belajar bagi anak-anak. Bunga rumput ini bisa dipakai pada saat kegiatan anak-anak mewarnai. Cara menggunakannya yaitu dengan mencelupkan bunga rumput tersebut kedalam mangkok warna yang sudah diaduk rata. Media ini juga aman untuk digunakan anak-anak.
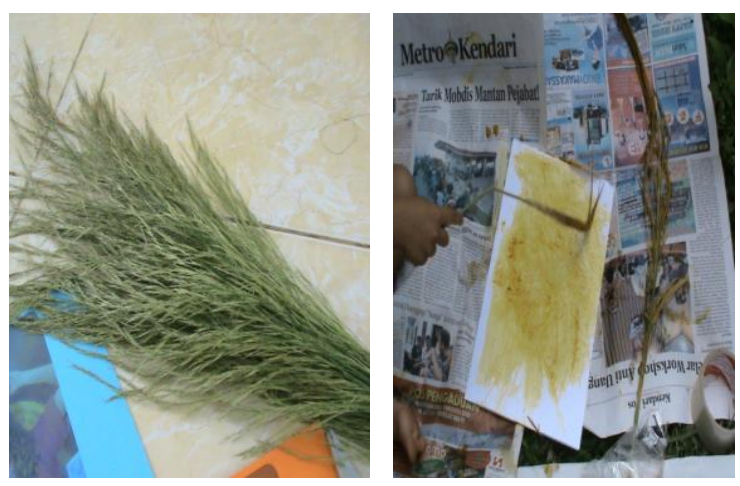

Gambar 9. Mewarnai Dengan Bunga Rumput

\section{MEWARNAI DENGAN PUTREN JAGUNG}

Putren jagung merupakan jagung kecil yang dihasilkan dari tanaman jagung biasa yang dipanen lebih awal. Bunganya dapat berwarna kuning, putih, dan merah tua tergantung dari varietasnya. Putren jangung ini biasanya diolah menjadi masakan tumis jagung putren yang bisa memberi manfaat untuk kesehatan pencernaan, menyeimbangkan tekanan darah, dan mencegah kanker. Selain bermanfaat bagi kesehatan tubuh putren jagung juga bermanfaat untuk media pembelajaran di TK, karena bisa digunakan untuk mewarnai gambar, mengaduk-aduk warna sampai merata dan lain-lain.

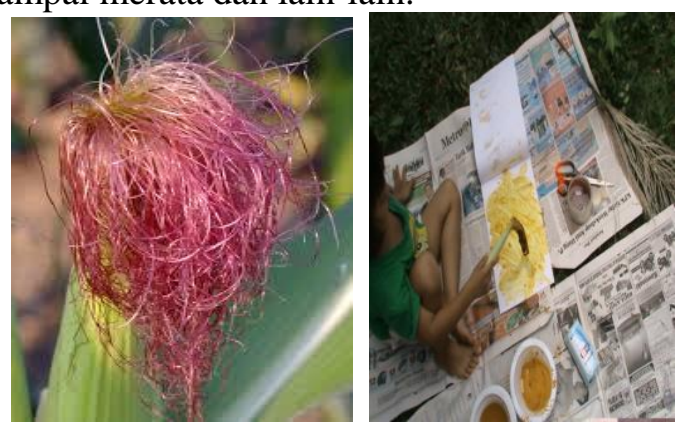

Gambar 10. Mewarnai Dengan Putren Jagung

\section{MEWARNAI DENGAN BUAH-BUAHAN (WORTEL)}

Wortel merupakan tanaman yang banyak mengandung karbohidrat dan sangat bermanfaat untuk kesehatan mata. Wortel juga sangat disukai oleh hewan kelinci. Wortel dapat pula digunakan sebagai media untuk mewarnai gambar oleh anak-anak. Potongan wortel dapat membentuk seperti bunga. Wortel juga dapat dijadikan sebagai bahan pewarna dengan cara di haluskan/diblender potongan wortel dan dicampurkan dengan air sedikit. Hasil perasan wortel berwarna orange.
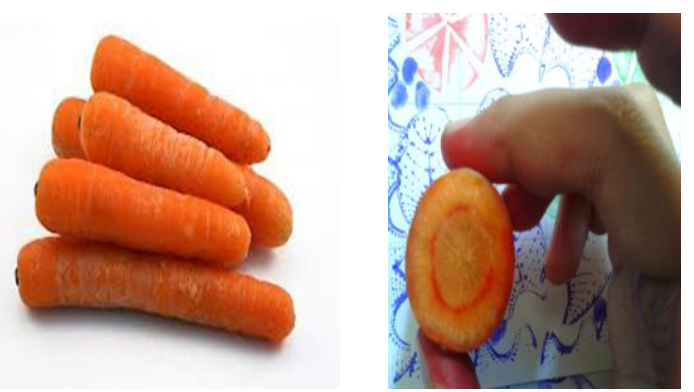

Gambar 11. Mewarnai Dengan Buah Wortel

\section{KEGIATAN MEWARNAI DENGAN MENGGUNAKAN ANEKA MEDIA DAPAT MENINGKATKAN KEMAMPUAN VISUAL-SPASIAL ANAK USIA DINI}

Kegiatan mewarnai menggunakan aneka media misalnya krayon, pensil warna, pelepah pisang, aneka tanaman misalnya kunyit, wortel dan lain-lain dapat meningkatkan kemampuan visual-spasial anak karena dengan aneka media warna dapat melatih ketajaman mata anak terhadap gambar-gambar yang sedang diwarnai. Selain itu juga melalui kegiatan mewarnai anak dapat mengenal berbagai warna, membedakan macam-macam warna, memadukan macammacam warna dan memilih macam-macam warna untuk digunakan mewarnai suatu gambar. Kegiatan mewarnai dengan menggunakan aneka media merupakan aktivitas yang menyenangkan bagi anak-anak sebab anak di beri kebebasan untuk memilih warna yang akan digunakan, anak diajak untuk memberi warna dengan menggunakan berbagai media baik saat menggambar atau meletakkan warna saat mengisi bidang-bidang gambar yang harus diberi warna pada suatu bentuk atau pola gambar, sehinga menciptakan sebuah kreasi seni. Kegiatan mewarnai sudah menjadi media untuk anak-anak berimajinasi, bereksplorasi dan 
berinspirasi melalui pengalaman yang telah mereka alami sebelumnya.

Kegiatan mewarnai juga digunakan sebagai media berekspresi, dapat mengenal perbedaan warna, dapat meningkatkan kosentrasi, melatih mengenai objek sehingga anak memahami detail objek yang akan diwarnai terlebih dahulu sebelum mereka mewarnai, melatih anak mengenal aneka warna dan nama-nama warna, melatih anak untuk memilih kombinasi warna dan membantu anak untuk belajar keserasian dan keseimbangan warna, dan dapat merangsang kepakaan anak terhadap warna dan merangsang kemampuan anak untuk memadukan warna.

Uraian di atas merupakan alasan mengapa kegiatan mewarnai dengan menggunakan berbagai media dapat mengembangkan kemampuan visual-spasial pada anak usia dini.

\section{PENUTUP}

Bermain merupakan aktivitas yang sangat penting dan menyenangkan dalam kehidupan anak. Ketika anak bermain ia bebas untuk berbuat apa saja. Dalam kegiatan bermain, khususnya kegiatan mewarnai pada aneka media dapat mengembangkan berbagai kemampuan anak salah satunya adalah kemampuan visualspasialnya.

\section{DAFTAR PUSTAKA}

Ali. 2003. Meningkatkan Kecerdasan Visualspasial Anak Usia Dini dengan Metode Bermain Bilding G_Block.

[Online]. Tersedia: http://repository.unib.ac.id/8707/1/1\%2C II\%2CIII\%2CII-14-san.FK.pdf. [10 November 2017].

Anonim. 2017. Days in Our Lives. [Online] Tersedia:

http://ayahbundaazzam.wordpress.com. [ 4 Desember 2017] . 2017. Mewarnai Gambar. [Online].

Tersedia:

http://belajarmenggambar.blogspot.co.id /p/teknik-mewarnai-gambar.html?m=1. [ 1 Desember 2017].
2017. Mewarnai dengan Pensil Warna. [Online].

Tersedia: https://www.google.com/search?q=mew arnai+dengan+pensil+warna\&ie $=$ utf$8 \&$ oe $=$ utf-8. [15 November 2017].

Armstrong. 2003. Pengembangan Kecerdasan Majemuk. Jakarta: Universitas Terbuka.

Busthomi, M. Yazid. 2012. Panduan Lengkap Paud. Yogyakarta : Citra Publishing

Fadillah, Muhammad. 2012. Desain Pembelajaran PAUD. Jogjakarta: Ar Ruzz Media

Muhammad. 2009. Pengertian Mewarnai. [Online]. Tersedia: www.jejak pendidikan.com . [ 9 November 2017].

Musfiroh, Tadkiroatun. 2008. Pengembangan Kecerdasan Majemuk. Jakarta: Universitas Terbuka.

Olivia. 2008. Belajar Membaca yang Menyenangkan Untuk Anak Usia Dini. Jakarta: Alex Media Komputindo

Sujiono. Yuliani Nurani. 2005. Konsep Dasar Pendidikan Anak Usia Dini. Jakarta: Indeks

Suyadi. 2009. Permainan Edukatif yang Mencerdaskan "The Power of Smart Games for Children. Jogjakarta: Power Books. 